\title{
Nutrients in Northern Missouri Streams
}

\section{Introduction}

Nutrients, specifically nitrogen and phosphorus, are necessary for healthy aquatic communities to thrive, but if nutrient concentrations are too high, water quality can be degraded and natural aquatic communities may be destroyed. Aquatic plant and algae growth often is controlled by the amount of nitrogen or phosphorus available, and elevated concentrations can lead to excessive growth. This condition, known as eutrophication, reduces light availability, aquatic habitat, and plant and animal biodiversity. Also, algal blooms (rapid and excessive accumulations of algae) can be toxic to humans, pets, and other animals; can increase treatment costs for drinking-water suppliers; can clog water-intake pipes; can reduce recreational abilities, such as fishing, swimming, and boating; and can result in oxygen concentrations too low to support aquatic life, causing fish and other animals to die off.

Nutrients consistently have been listed nationally as one of the top five causes of stream and river impairments in the National Water Quality Inventory Report to Congress, and agriculture consistently has been identified as the leading known source of impairments in assessed streams and rivers (U.S. Environmental Protection Agency, variously dated). The Mississippi River watershed was identified as a top priority for nutrient reductions by the U.S. Department of Agriculture Natural Resources Conservation Service (NRCS) because of the predominant agricultural land use, the associated harmful effects of nutrient loading on local water bodies, and the resulting annual midsummer northern Gulf of Mexico hypoxic "dead" zone in which dissolved oxygen concentrations are too low to support aquatic life (Rabalais and others, 2002). The northern Missouri streams and rivers included in this report are part of the Mississippi River watershed and the primary land use is agriculture. Nutrients that enter these waterways have a direct path to the Mississippi River and can contribute to the Gulf of Mexico hypoxic "dead" zone.

\section{Mississippi River Basin Healthy Watersheds Initiative}

In 2010, the NRCS started the Mississippi River Basin Healthy Watersheds Initiative (MRBI). This program offers financial and technical assistance to agricultural producers in priority areas for voluntary conservation practices on agricultural lands (NRCS, variously dated). The intention is to reduce nutrient and sediment export to waterways while improving infield soil health. The Lower Grand River hydrologic unit in Missouri and Iowa (fig. 1; hereafter referred to as the "Lower Grand River") is an MRBI priority area.

\section{Nutrients in Northern Missouri Streams}

The U.S. Geological Survey (USGS) and the Missouri Department of Natural Resources began a cooperative study in 2010 to compare temporal changes in total nitrogen (TN) and

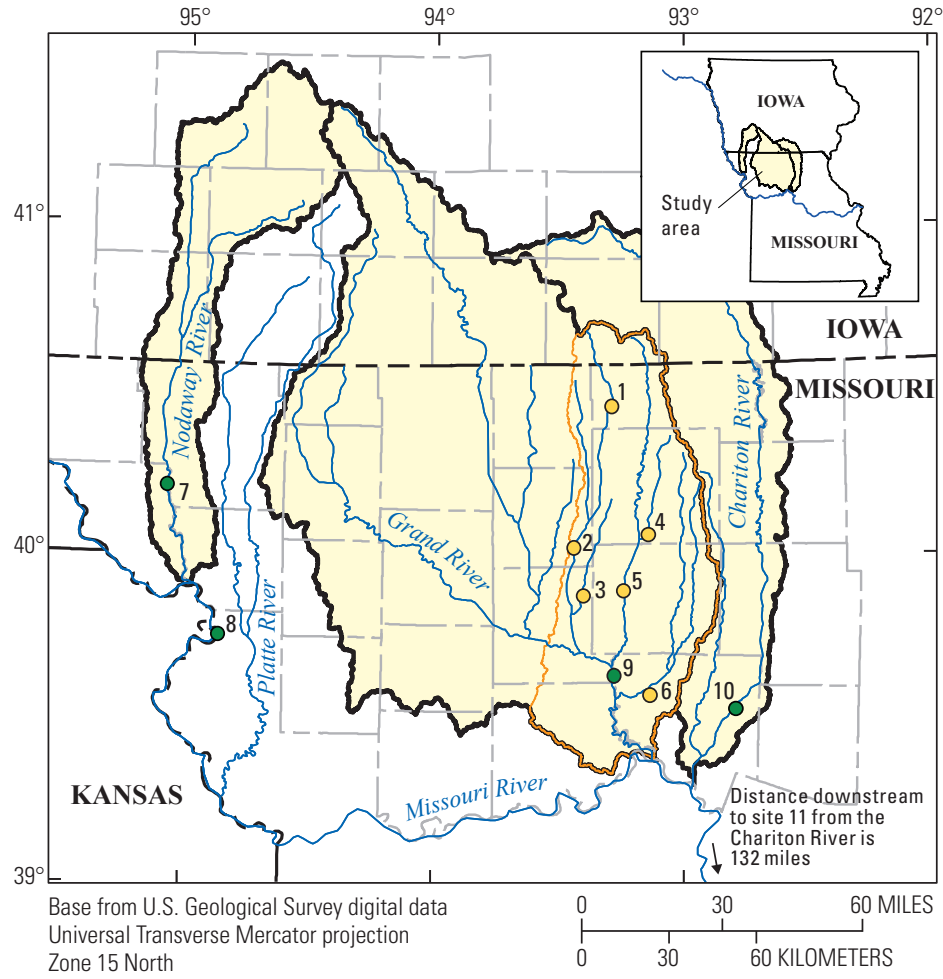

EXPLANATION

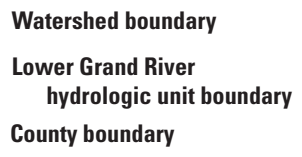

Watershed boundary

Lower Grand River hydrologic unit boundary County boundary

\section{O 7 Long-term site and identifier \\ O 1 Mississippi River Basin Healthy Watersheds Initiative site and identifier}

Figure 1. Locations of U.S. Geological Survey long-term waterquality collection sites within or near the Lower Grand River and the Mississippi River Basin Healthy Watersheds Initiative sites within the Lower Grand River, Missouri and lowa. Modified from Krempa and Flickinger (2017).

\section{Sources of Nitrogen and Phosphorus}

- Agricultural field drainage culverts

- Fertilizer from urban lawns, golf courses, and agriculture

- Pet, livestock, and wildlife waste

- Wastewater treatment plants

- Industrial discharges

- Combustion of fossil fuels

- Decomposing organic matter 
total phosphorus (TP) concentrations in the Lower Grand River. Also, previously collected data were used to compare longer term temporal changes in TN and TP concentrations in other northern Missouri streams (Krempa and Flickinger, 2017).

\section{Study Design}

Nutrient monitoring sites for this study included 6 locations on Lower Grand River tributaries (MRBI sites; sites 1-6; fig. 1) and 5 long-term locations monitored for other studies (with 20 years or more streamflow, total nitrogen, and total phosphorus data), including 3 other Missouri River tributaries (sites 7, 9, and 10; fig. 1) and 2 sites on the Missouri River (sites 8 and 11; fig. 1; Krempa and Flickinger, 2017). Concentrations of TN and TP were compared temporally and among sites. Long-term nutrient changes were evaluated relative to conservation practices and agricultural activities. Agriculture is the primary land use within the Lower Grand River and the other Missouri River tributary watersheds; however, the Lower Grand River was the only hydrologic unit in this study considered an MRBI priority with additional funding available for NRCS conservation practices. Detailed study methods and results are available from Krempa and Flickinger (2017).

\section{Nutrient Concentration Changes and Agricultural Practices}

Temporal changes in annual flow-normalized TN and flownormalized TP concentrations generally were similar among long-term sites (sites 7-11), with increases and decreases occurring during similar periods (fig. 2). Flow-normalized TN and TP concentrations have decreased at all long-term sites (sites 7-11) since water year 2008, with the exception of TP at site 11, which increased. This indicates that similar processes may be driving nutrient concentrations within these watersheds.

Despite increases in conservation practice funding from the MRBI during 2011-15 for the Lower Grand River, decreases in flow-normalized TN and TP concentrations during this same period at the Grand River site (site 9) were less than at the other long-term Missouri River tributary sites (sites 7 and 10; fig. 2) that did not receive additional funding (Krempa and Flickinger, 2017). There are several possible explanations for smaller decreases at the Grand River site. First, there is an unknown duration of time, known as "lag time," between land management changes (including conservation practices) and measurable changes in stream $\mathrm{TN}$ and TP concentrations. Second, the increases in the amount of conservation practices within the Lower Grand River may not have been substantial enough to reduce stream TN and TP concentrations. Also, at least 50 percent of the financial support each calendar year during 2011 through 2015 was on terraces and underground outlets. The purpose of terraces is to reduce erosion and retain runoff (NRCS, 2014), and the purpose of underground outlets is to carry water to a suitable outlet without causing damage by erosion or flooding (NRCS, 2013). These two types of conservation practices may not effectively reduce nutrients entering waterways because they are focused on reducing erosion and not nutrients.

The flow-normalized TN and TP concentrations at the three long-term Missouri River tributary sites (sites 7, 9, and 10) were related to the amount of agricultural land use within their watersheds. During the long-term sampling periods, the highest TN and
TP concentrations were at the site with the most agricultural land use ( 85 percent), the Nodaway River site (site 7), whereas the lowest concentrations were at the site with the least agricultural land use (63 percent), the Chariton River site (site 10). The TN and TP concentrations and percentage of agricultural land use (74 percent) at the Grand River site (site 9) were between the other two longterm tributary sites (fig. 2).

Study results indicate that livestock manure may be a substantial source of stream nitrogen, especially within the Grand River and Chariton River (sites 9 and 10) watersheds (Krempa and Flickinger, 2017). Commercial fertilizer use estimates were not strongly correlated with changes in flow-normalized TN and TP concentrations at these sites (absolute values of correlation coefficients were less than or equal to 0.50 ). However, because of limited data availability, the methods used to estimate annual nitrogen and phosphorus from commercial fertilizer for each watershed may not be representative of the amount of commercial fertilizer applied within the watershed. Also, study results did not indicate that increases in conservation reserve program acres, which take agricultural land out of production, were related with decreases in flow-normalized TN and TP (Krempa and Flickinger, 2017).

Monthly TN and TP concentrations within the Lower Grand River increased with increased streamflow (fig. 2), indicating that the major sources of nitrogen and phosphorus are runoff or nutrients that are stored in soils within the streambank that mobilize during higher streamflows. Nutrients accumulate in runoff as water flows over the land carrying nonpoint source pollution to waterways. If nutrient sources were dominated by groundwater or consistent point sources, precipitation and runoff would have a diluting effect and TN and TP would decrease with increased streamflow.

\section{Reducing Nutrients in Waterways}

Excessive nutrients in streams can have many immediate and lasting effects, but reducing the overall amount of nutrients available and reducing and slowing runoff, which allows nutrients to be taken up by plants, can reduce the amount of nutrients that enter our waterways. Programs such as the MRBI are intended to encourage voluntary agricultural conservation practices to enhance soil health and reduce nutrient export to streams. Agricultural practices that can reduce nutrients in waterways include, but are not limited to, increasing buffer zones around waterways, utilizing nutrient management practices to reduce the amount of fertilizer applied, building fences to prevent livestock from entering streams, using no-till and cover crop practices, and restoring critical wetland areas.

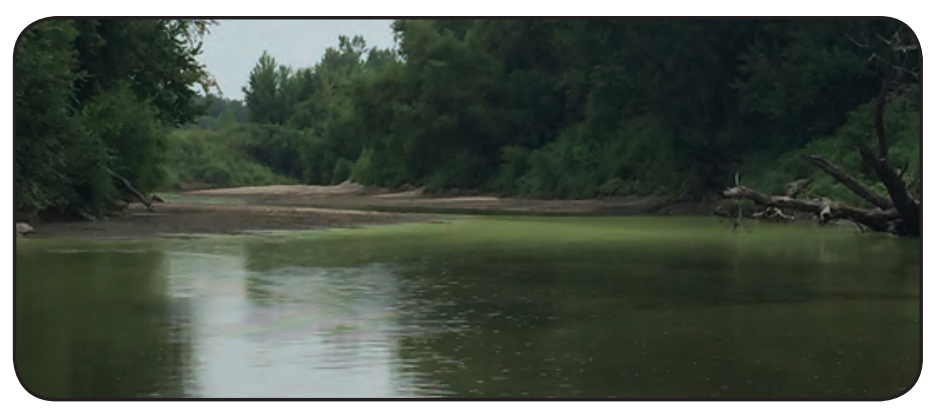

Surface algae at Locust Creek near Linneus, Missouri (site 5; U.S. Geological Survey station 06901500). 


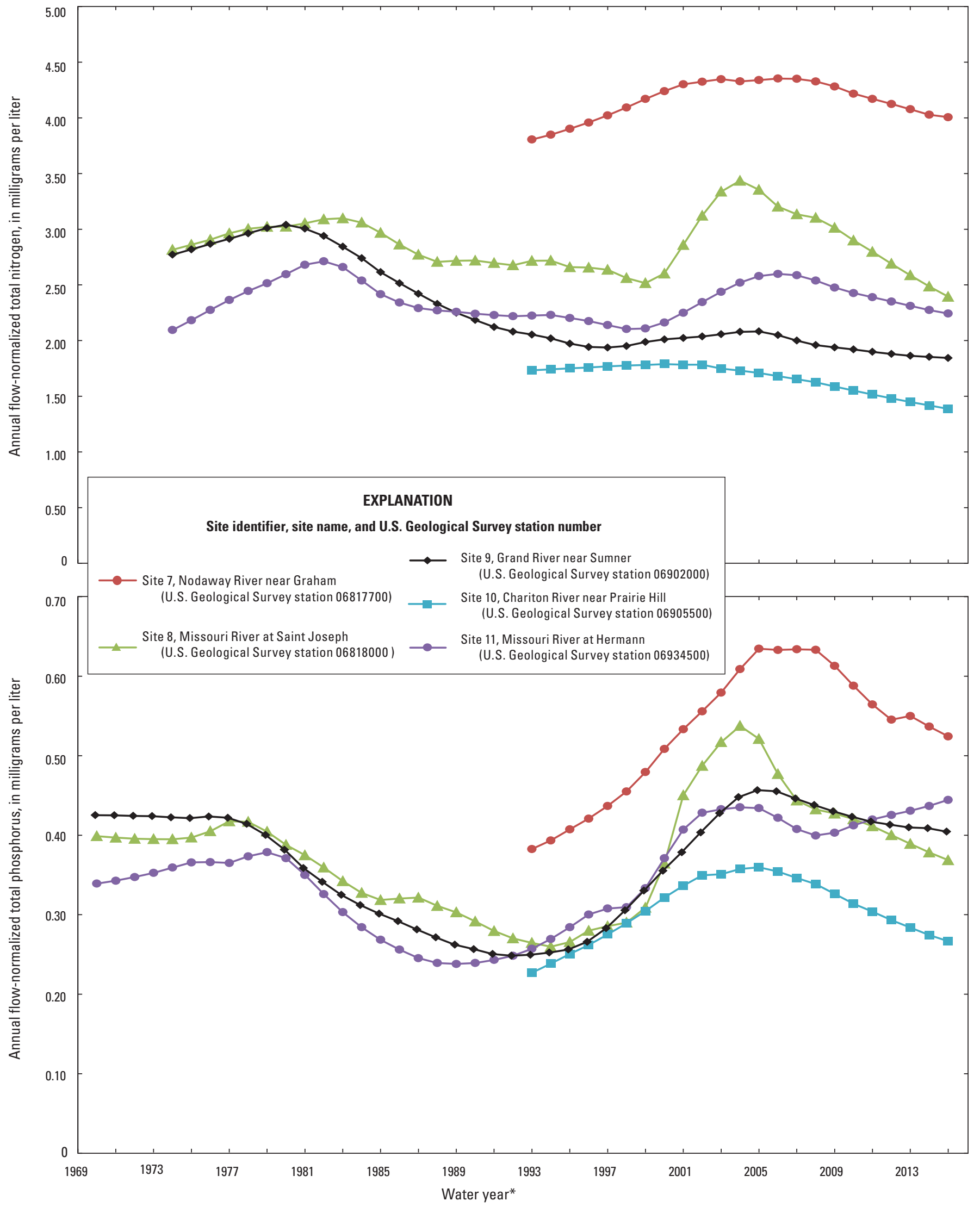

${ }^{*}$ A water year is the period from October 1 to September 30 and is designated by the year in which it ends

Figure 2. Annual flow-normalized total nitrogen and total phosphorus concentrations at five selected long-term monitoring sites (sites 7-11), Missouri. Modified from Krempa and Flickinger (2017). 


\section{Things You Can Do to Reduce Nutrients in Waterways}

- Pick up pet waste

- Keep pet and livestock waste away from waterways

- Avoid use of excess fertilizer or avoid using fertilizer

- Avoid fertilizing before and on windy or rainy days

- Reduce runoff by using a soaker hose or avoid overwatering your lawn

- Use cleaners labeled as "phosphate free"

- Use soap conservatively

- Inspect septic systems

- Reduce energy consumption and driving time

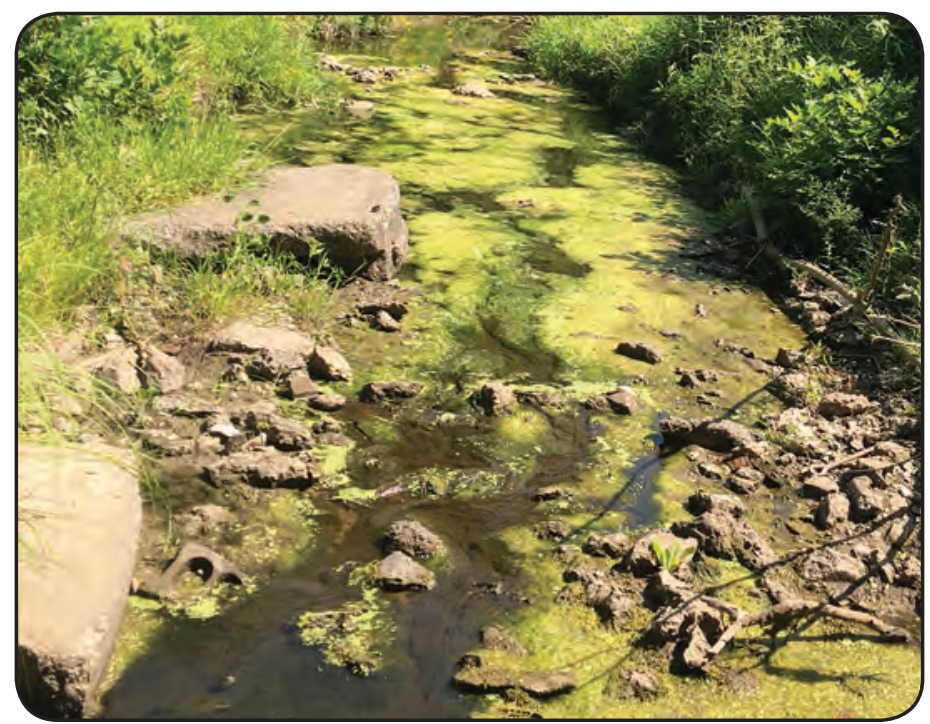

Algal bloom at Hickory Branch near Mendon, Missouri (site 6; U.S. Geological Survey station 06902995).

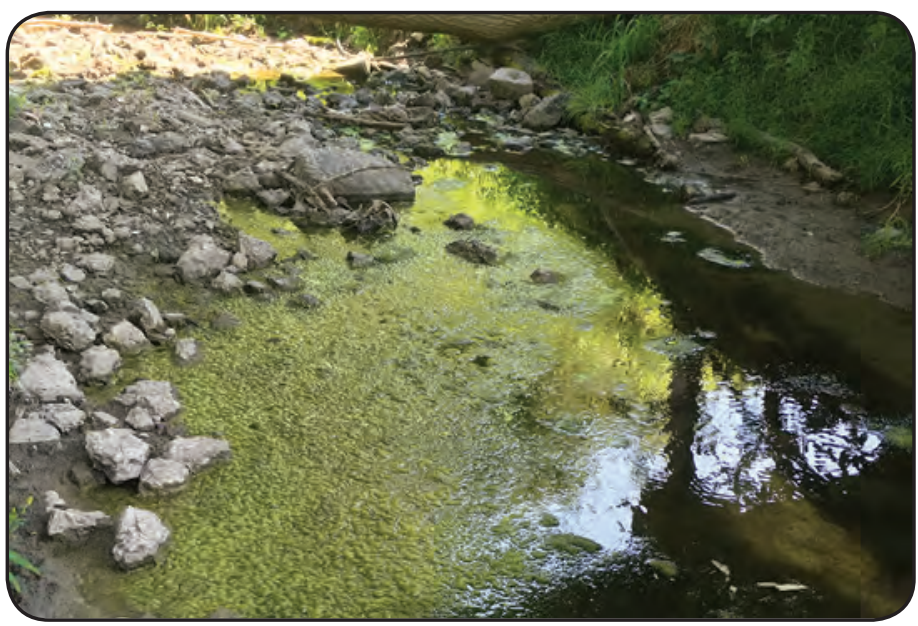

Algal bloom at Hickory Branch near Mendon, Missouri (site 6; U.S. Geological Survey station 06902995).

\section{References Cited}

Krempa, H.M., and Flickinger, A.K., 2017, Temporal changes in nitrogen and phosphorus concentrations with comparisons to conservation practices and agricultural activities in the Lower Grand River, Missouri and Iowa, and selected watersheds, 1969-2015: U.S. Geological Survey Scientific Investigations Report 2017-5067, 28 p. [Also available at https://doi.org/10.3133/sir20175067.]

Natural Resources Conservation Service [NRCS], 2013, Conservation practice standard-Underground outlet: U.S. Department of Agriculture, Natural Resources Conservation Service, Conservation Practice Standard code 620, p. 1, accessed October 26, 2016, at https://www.nrcs.usda.gov/Internet/ FSE_DOCUMENTS/stelprdb1241324.pdf.

Natural Resources Conservation Service [NRCS], 2014, Conservation practice standard-Terrace: U.S. Department of Agriculture, Natural Resources Conservation Service, Conservation Practice Standard code 600, p. 1, accessed October 26, 2016, at https://www.nrcs.usda.gov/Internet/ FSE_DOCUMENTS/stelprdb1263187.pdf.

Natural Resources Conservation Service [NRCS], variously dated, Mississippi River Basin Healthy Watersheds Initiative: U.S. Department of Agriculture, Natural Resources Conservation Service web page, accessed October 26, 2016, at https://www.nrcs.usda.gov/wps/portal/nrcs/detailfull/national/ home/?cid=stelprdb1048200.

Rabalais, N.N., Turner, R.E., and Wiseman, W.J., Jr., 2002, Gulf of Mexico hypoxia, a.k.a. "The Dead Zone": Annual Review of Ecology and Systematics, v. 33, no. 1, p. 235263. [Also available at https://doi.org/10.1146/annurev. ecolsys.33.010802.150513.]

U.S. Environmental Protection Agency, variously dated, National water quality inventory report to Congress: U.S. Environmental Protection Agency web page, accessed May 25, 2016, at https://www.epa.gov/waterdata/national-waterquality-inventory-report-congress.

By Heather M. Krempa

For further information, please contact Director, Central Midwest Water Science Center U.S. Geological Survey 1400 Independence Road

Rolla, M0 65401

(573) 308-3667

https://www.usgs.gov/centers/cm-water 